\title{
PROBLEMS OF THE SELECTION OF CONSTRUCTION TECHNOLOGY FOR STRUCTURES IN THE CENTRES OF URBAN AGGLOMERATIONS
}

\author{
E. RADZISZEWSKA-ZIELINA ${ }^{1}$, E. KANIA ${ }^{2}$, G. ŚLADOWSKI ${ }^{3}$
}

\begin{abstract}
The goal of the article is the diagnosis and presentation of the problems of the selection of construction technologies for buildings being built in the centres of urban agglomerations. The survey and literature studies that were performed show that the process of selecting these technologies is difficult due to a series of very different difficulties associated with constructing a structure in a city centre and which are sometimes hard to foresee. At the same time there is a lack of decision-making support tools dedicated to the selection of construction technologies that would take into account the problems that occur during the construction of buildings in city centres. The study shows the need to discuss the subject of developing a mathematical model and a decisionmaking support tool based on said model to that end.
\end{abstract}

Keywords: technology, organisation, construction projects, urban agglomeration

\section{INTRODUCTION}

Along with the development of civilisation, a development of the technologies of carrying out construction projects and the capabilities of civil engineering has taken place. The expectations of decision-makers to build faster, more and construct taller buildings have increased as well. The rising population numbers and technological progress have led to the emergence of urban agglomerations

\footnotetext{
${ }^{1}$ Assoc. Prof. PhD. Eng., Cracow University of Technology, Faculty of Civil Engineering, ul. Warszawska 24, 31-155 Cracow, Poland, e-mail: eradzisz@izwbit.pk.edu.pl

${ }^{2}$ M.Sc. Eng., Cracow University of Technology, Faculty of Civil Engineering, ul. Warszawska 24, 31-155 Cracow, Poland,

${ }^{3} \mathrm{PhD}$. Eng., Cracow University of Technology, Faculty of Civil Engineering, ul. Warszawska 24, 31-155 Cracow, Poland, e-mail: gsladowski@L3.pk.edu.pl
} 
that concentrate a significant and constantly increasing number of construction projects. The carrying out of a construction project located in an urban agglomeration is currently associated with various technological and organisational problems that evolve along with it.

A construction project is a development effort undertaken in order to meet the needs of a developer and of its future users. A construction project includes work meant to prepare, organise and perform construction work, settle its accounts and hand over a finished product ready for operation [23, 24]. The carrying out of a construction project is a highly complicated process that is dependent on nonrepeatable external factors and its own individual characteristics. The basic characteristics of a construction project include:

- the individual character of a construction project and the form of use of the structure being built,

- the natural environment and direct interference within it (the permanent binding of a structure with the site of its construction, water and soil conditions),

- the space in which construction is being performed, the need to manage it,

- the long duration of carrying out a project,

- a set budget,

- a proper quality of construction work (special technical, functional and economic requirements),

- local legal regulations,

- the active cooperation of stakeholders: the developer, designer and contractor,

- a large number of contractors performing work on a structure, the cooperation of numerous specialists and companies (designers, construction engineers and workers, suppliers, material and machinery manufacturers),

- high costs of machines and manpower,

- the diversity of construction technologies,

- the seasonal nature of the work being performed (the capacity to perform construction work varies throughout the year: it is higher in summer and lower in winter),

- the development of new technologies and technological progress, enabling the dynamism of construction services,

- random factors such as: atmospheric conditions, logistics problems, changes in human resources, equipment failure [2, 3, 13, 15, 18, 22, 34, 36, 65]. 
Areas that feature the highest construction project density are urban agglomerations. Urban agglomerations are defined as areas with very dense built-up areas, a high population density composed of people who either temporarily reside within them (e.g. during the day) or who constitute their permanent residents. Such areas are characterised by rapid spatial development, as they form tightly integrated groupings of neighbouring cities, towns and villages with a well-developed infrastructure and broadly understood socio-economic and cultural conditions [11].

The rapid development of urban agglomerations often causes the construction of structures in their centres to be associated with technical and organisational problems. In our previous article [47] we had pointed to these problems and developed guidelines regarding the carrying out of construction projects located in the centres of urban agglomerations on the example of a selection of presented case studies. Many other authors also pointed to the diverse problems that appear during construction, especially when it is performed in the centre of an urban agglomeration. Difficulties occurring during the construction process and the importance of logistics in construction was pointed out by the authors of $[21,27,32,37,56,57,59,63]$. Of substantial significance to the carrying out of construction work is the problem of dense built-up areas, which was highlighted by the authors of other publications $[17,55,64]$. This is associated with another problem, which is the need to dig deep excavations and the difficulties associated with it $[1,4,10,40]$, and at the same time the need to build very tall buildings $[8,41]$. Limited construction site space and the lack of storage yards are a characteristic element that appears in the carrying out of construction projects in the centres of urban agglomerations $[42,60,62]$. Due to various factors, mainly the impact of circulation, dynamic loads are exerted on the structure being constructed, as well as on the surroundings of the project site [6, $16,28,33,61]$. At the same time, the residents of the area surrounding the structure being built are affected by noise, dirt and traffic difficulties [5, 9, 66, 67]. In large urban agglomerations the administrative factor associated with the carrying out of construction projects tends to be quite robust, as appropriate procedures regulate projects that are being funded from a municipality's public funds, while at the same time all manners of approvals and official decisions are required [7, 12, 25, 26]. These are accompanied by the requirements of developers (e.g. a more representative structure, in the case of a multiple-structure project, has to be built first, from the side of a high traffic street) [14, 20, $35,68]$. The areas of urban agglomerations often feature a large number of historical structures which are important from a historical point of view. Renovation work performed on such structures is highly complicated and requires specific solutions, in addition to being characterised by a significant amount of unplanned additional work that is difficult to foresee $[29,48,49,50]$. 
The appropriate selection of the technology of the construction of a structure is one of the more important decisions that need to be made. A decision-maker has the option to consider at least a couple of alternatives in terms of construction technology [19], for instance:

- prefabricated concrete construction technology,

- monolithic concrete construction technology,

- monolithic and prefabricated concrete construction technology,

- metal construction technology,

- timber construction technology,

all of which are possible to use in dense urban built-up areas. The abovementioned selection problem has a multi-dimensional character due to a large amount of factors that determine the appropriate selection of construction technology [30, 31, 38, 39, 51, 52, 54].

The goal of the article is to discuss the problems of the carrying out of construction projects in the centres of urban agglomerations and the manner of the selection of construction technology for a structure, based on a survey study performed by the authors.

\section{RESEARCH METHOD}

Survey studies are an appropriate research method, making it possible to obtain useful information that can be used to confirm the need for wider scientific research of a given topic and to provide tools to solve existing problems [58]. This study discusses the problem of the selection of a construction technology in light of the constraints that appear in the centres of urban agglomerations. A survey study has been performed on a group of experts from the construction sector. The authors of the article prepared a questionnaire composed of two parts: a filtering questionnaire and the main questions. A group of experts was interviewed. Information on the subject of three fields of study was gathered:

1. Opinions regarding the problem of the carrying out of construction projects in the centres of urban agglomerations

2. Methods of the selection of construction technologies, especially for a structure being built in the centre of an urban agglomeration

3. Opinions about the need to develop a tool (a digital system), which could support decisionmaking in terms of selecting a construction technology for a structure that is to be built in the centre of an urban agglomeration. 


\section{RESEARCH SAMPLE SELECTION}

The research sample consisted of 11 experts selected on the basis of a filtering questionnaire (Contract managers, Construction site directors, Construction work directors). Three criteria needed to be met (fig. 1) by the experts. The first criterion was years of work experience in the construction sector. The minimum amount of work experience in the construction sector was 10 years, a condition that was met by nine respondents, while the two remaining respondents had worked in the construction sector for over 20 years. All of the participants of the study carried out contracts worth over 50 million PLN and projects that were located in city centres. The construction projects that were carried out by the experts were located in Poland's largest cities, including Warsaw, Krakow, Poznań, Łódź, Wrocław, Opole, Katowice, Gdynia, Gdańsk, as well as abroad - in Berlin, Dusseldorf, Koln, Munich, Stuttgart, and Frankfurt am Main. The buildings that were built by the experts are the hallmarks of their careers in the construction sector. Examples of the construction projects that were carried out by the experts in the capacity of Contract managers, Construction site directors and Construction work directors include: the Sky Tower complex in Wrocław, the High5ive office and commercial buildings complex in Krakow, the Ostrów Tumski Interactive Centre in Poznań, Galeria Młociny in Warsaw, the Baltic Arena in Gdańsk, the Equator office building in Warsaw, the Port Łódź commercial and retail centre in Łódź, the ATM film studio in WArsaw, the NIMBUS conference centre in Warsaw, the Bonarka City Centre complex in Krakow, the Pasaż Podgórski housing development in Krakow, the Bundestag building in Berlin, the Tunnel beneath the Martwa Wisła River in Gdańsk, the Heart Surgery Hospital in Munich, the Mac Nair housing development in Berlin.

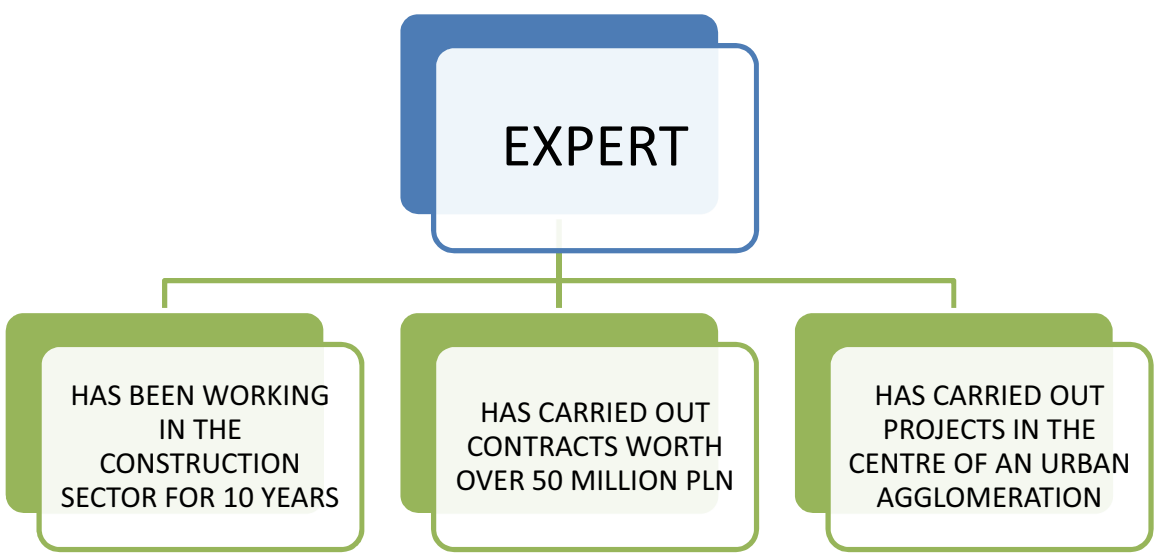

Fig. 1. Requirements for experts according to the filtering questionnaire. Original work 


\section{PROBLEMS OF CARRYING OUT CONSTRUCTION PROJECTS IN THE CENTRE OF AN URBAN AGGLOMERATION}

The carrying out of a construction project in the centre of an urban agglomeration, as can be seen based on the literature review performed at the start of the article, causes many technological and organisational problems. This fact was confirmed by $100 \%$ of the surveyed practitioners.

Each of the experts mentioned a number of problems and difficulties that appear and that are associated with the construction of structures in city centres. These problems are sometimes mentioned numerous times, although it is well known that every development project is unique and there are no two identical construction projects.

The problem that is highlighted the most often is that of broadly understood logistics, both at the construction site, as well as regarding the entirety of a city. The large scale of construction projects, combined with the constraints of construction sites, causes problems in terms of the organisation of space, and these, in turn, cause more problems in and of themselves. Due to very high land prices of plots located in the centres of urban agglomerations, the highest possible amount of land gets builtup as a result of construction. This is the reason why there is a lack of storage yards, which forces contractors to perform many additional tasks. Work becomes more difficult to a large extent, as there is no possibility to order materials and supplies in advance. Detailed delivery schedules need to be prepared and rigorously adhered to, because the elements being delivered are usually assembled directly off of the lorry, without being stored at the construction site beforehand.

There is also the problem with the deliveries themselves, due to delays caused by traffic jams and other factors. These difficulties are particularly significant in the case of the delivery of materials with a strict suitability window, examples of which are concrete mixtures or cements delivered from concrete plants. This generates additional costs and negatively impacts the environment. A concrete mixture that can no longer be used is sent back to the concrete plant, where it must be processed, while a new concrete transportation vehicle is being sent with a new concrete mixture batch. In this case a double "dose" of vehicle exhaust gets emitted into the atmosphere along the route between the construction site and the concrete plant. 
Another factor that makes deliveries difficult is the fact that it is not possible to reach every location with a large delivery vehicle (e.g. deliveries can only be performed using vehicles that are $6 \mathrm{~m}$ long in some cases).

In the case of building structures in large cities, the need to requisition street lanes and pavements for the purposes of unloading materials and concreting elements is very common. This is associated with obtaining numerous approvals from municipal offices, introducing temporary traffic organisation and additional costs (funds need to be allocated in the contract for the repair of any damage to elements of a street and the hiring of employees to clean the road after construction work has finished).

The work of truck-mounted and tower cranes is often constrained by the height of power lines. The close proximity of tram and railway lines is very common in large cities. Apart from difficulties associated with the height of power lines, trams and trains generate high dynamic loads that affect the structure that is being built. At the same time, the work being performed at the construction site also causes vibrations, which affect other buildings in the immediate vicinity. It is very important to constantly monitor the structure being built, along with the neighbouring buildings, in terms of the influence of dynamic loads.

The height of structures is constrained in urban zones and defined in a local spatial development plan. This largely results in the necessity to build a number of additional underground levels fulfilling the role of parking facilities. Due to the close proximity of the surrounding buildings and varied water and soil conditions, there is no possibility of using traditional excavation technologies. Costly specialist excavation reinforcement is required, making it possible to perform construction work in the conditions of the centre of an urban agglomeration.

Cities feature dense residential built-up areas, which make it impossible to perform work during night time.

In summary of the subject of the problems and constraints of carrying out of construction projects in the centres of urban agglomerations, the more important factors have been presented on the graph below (fig. 2). 


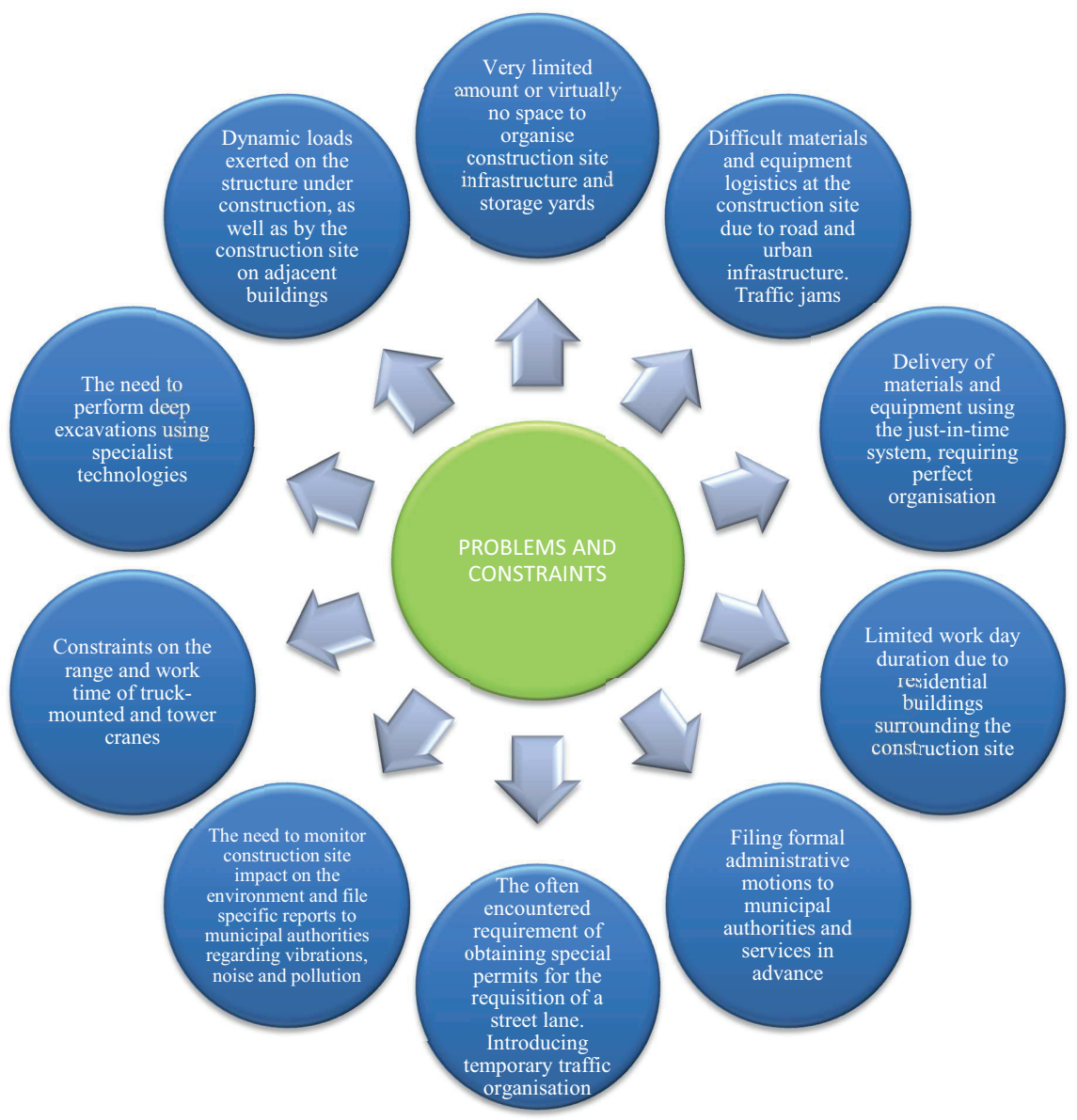

Fig. 2. Graph showing examples of constraints and problems that appear during the carrying out of construction projects in the centres of urban agglomerations. Original work based on interviews with experts.

\section{PROBLEM OF THE SELECTION OF CONSTRUCTION TECHNOLOGY FOR STRUCTURES BEING BUILT IN THE CENTRES OF URBAN AGGLOMERATIONS}

A properly selected construction technology can greatly affect the success of a given project. The difficulties that appear in large urban agglomerations can impact the selection of technology (fig. 3) 
and, as most experts have stressed, an appropriately selected technology can either completely or, to a certain degree, alleviate the influence of these difficulties on the carrying out of a construction project (fig. 4).

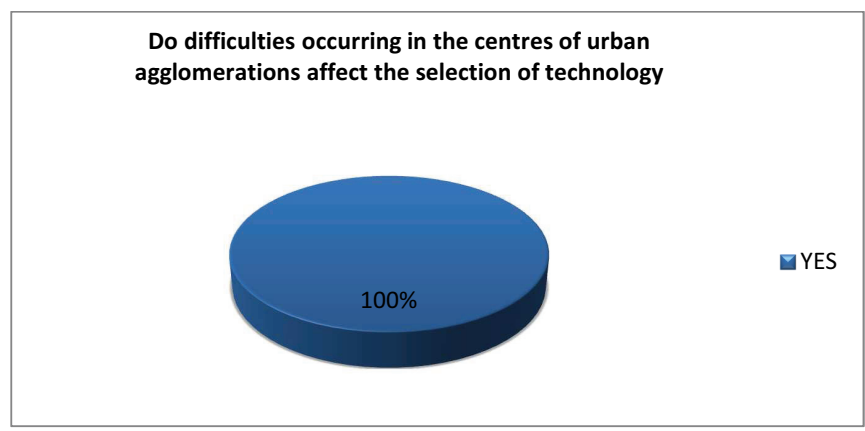

Fig. 3. Results of the survey study, showing whether experts agreed that the difficulties that occur in the centres of urban agglomerations can have an effect on the selection of construction technology for a construction project. Original work

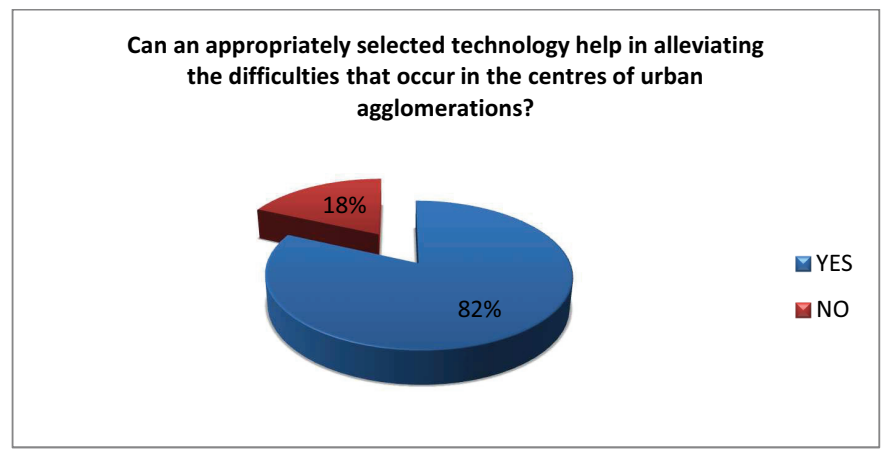

Fig. 4. Results of the survey study, showing whether experts agreed that an appropriately selected technology can completely or partially alleviate the difficulties resulting from carrying out a construction project in the centre of an urban agglomeration. Original work

The experts were then asked whether there is cooperation between the designer and general contractor over the entire course of the development process. Answers to this questions have been presented on figure 5 . 


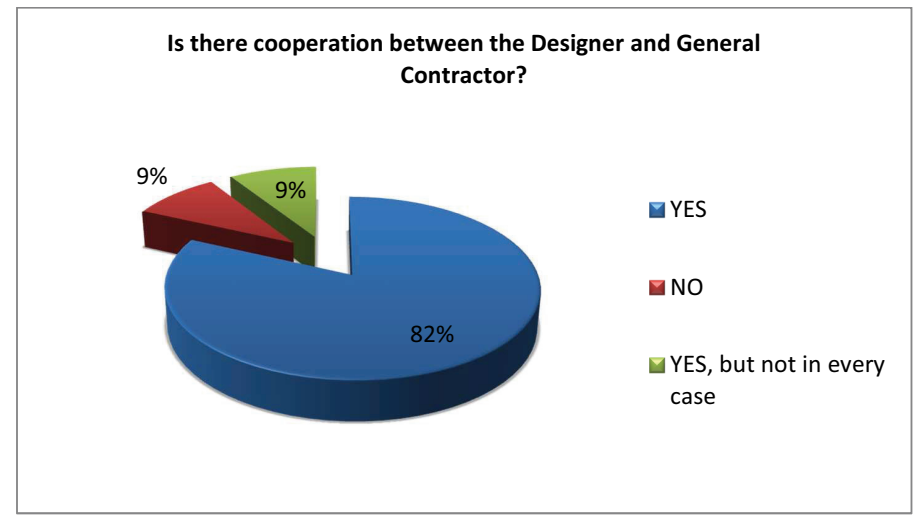

Fig. 5. Results of the survey study showing whether the experts agreed that there is cooperation between the Designer and General Contractor. Original work

The study that was performed shows what the main element of the cooperation between a Designer and General Contractor of a project is. There are numerous publications on the subject of good (partnering) cooperation between the participants of construction projects [43, 44, 45, 46, 53]. The survey study was also a search for the answer to the question regarding who, in practice, suggests the appropriate construction technology (the Developer, Designer or the General Contractor) and who gets to make the final decision on the matter.

In most cases, the surveyed experts answered positively to the question regarding the existence of cooperation between General Contractors and Designers. A General Contractor can suggest changes to a design (interference in the design due to technological changes making it possible to perform construction work quicker and shorten the overall duration of the project). At the same time, both sides search for the most beneficial solution, analysing the situation based on the difficulties that occur at the construction site and in its vicinity, as well as mainly analysing the project in terms of its finances and duration. The technical and detailed design documentation is mutually controlled, in addition to the detection and solving of any problems regarding any incompatibility between each document (textual and graphical parts of the design), as well as the solving of any problems that appear over the course of construction.

According to the opinions of experts, a General Contractor or Developer has the right to suggest proposals regarding the selection of construction technology, both during the design, as well as the construction stage of a project. Most of the time, such actions are taken when: 
a. the clauses of the agreements between the ordering party and the General Contractor or the ordering party and the Designer allow this,

b. when it is allowed by environmental conditions or when maintaining the characteristics of environmentally friendly construction is one of the required standards (LEED or BREEAM certification),

c. there are no other restrictions contained in the construction permit or that may result from a project's location,

d. standards regarding the protection of National Heritage in the case of historical structures need to be considered,

e. standards represented by the General Contractor or Developer need to be considered (e.g. health and safety standards).

Examples of such suggestions derived from the practical experience of experts include:

a. changing the technology of soil reinforcement,

b. changing the technology of constructing the foundations and underground section of a structure, which is also sometimes associated with changes to its structure (e.g. replacing foundation pads with a diaphragm slab or a slab with expansion joints),

c. changing the technology of the structural concrete elements from monolithic ones to prefabricated ones,

d. changing the technology of floor layers,

e. changing the technology of the structure of the floor slabs to include semi-prefabricated elements, layered walls, prefabricated elements, modular rooms, i.e. toilets - bathrooms, soil pipes, walls and elements of the stair runs of stairwells, the structural couplings of concrete elements constructed with a construction or expansion joint, constructing expansion joints as watertight, etc.

The experts had different experiences regarding the manner of making decisions about technology. Most of them highlighted the fact that decisions are made after analysing all the factors that either obstruct or increase construction capacity. Consultations and meetings of all stakeholders are held: including the Developer, General Contractor and Designer. The influence of the selected construction technology on the cost duration and quality of construction work is analysed. The final decision regarding the selection of the construction technology to be used is often an individual, final assessment of the situation by one of the parties based on analysing all options and constraints (fig. $6)$. 


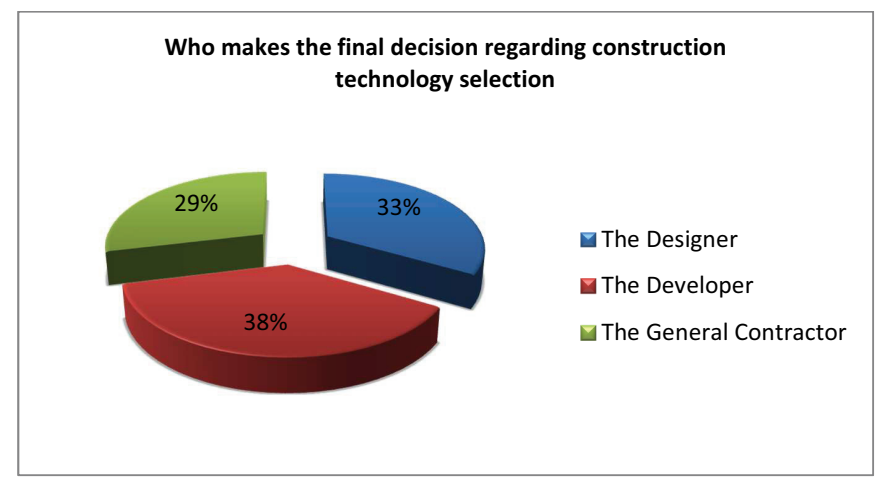

Fig. 6. Results of the survey showing who, in practice, makes the final decision regarding technology selection. Original work

The decision-makers were also asked whether they used any decision-making support computer programs to make their decisions regarding the selection of construction technology. All of the experts stated that there is a lack of such programs. None of the decision-makers knew of any program that was specifically meant to select construction technology. One of the experts pointed to BIM technology that he had used, also mentioning that it is a tool that makes it possible to create a virtual model of a building before actual construction takes place, in order to solve problems that can occur during construction and to simulate and analyse the potential results of actions. $82 \%$ of the respondents see the need for and would be interested in using a new digital decision-making support tool for the selection of an appropriate construction technology for a structure being built in the centre of an urban agglomeration.

\section{CONCLUSION}

Based on the survey study performed by the authors, we can state that the carrying out of a construction project in an urban agglomeration is not an easy task. In addition, the selection of the construction technology in which a structure is to be built is a controversial matter. There is a lack of decision-making support tools for this problem. In most cases the decision is made based on discussions between the participants of the process and on the basis of individual experience. The research that has been presented is thus a justification of and an introduction to undertaking the subject of developing a decision-making support tool (a digital system) that will be useful in making decisions 
regarding the selection of construction technology for structures to be built in the centres of urban agglomerations.

\section{REFERENCES}

1. A.J. Alzamora, L.E. Ford, A.J. Ciancia "Case studies of new york city projects with varying site constraints" International Foundations Congress and Equipment Expo 2015, 256, 1522-1535, 2015

2. D. Baccarini,.,,The concept of project complexity - A review” International Journal of Project Management, 14, 201204, 1996

3. J. Bizon-Górecka, J.Górecki „Influence of Selected Stakeholders of Construction Investment Projects on the Course of Project" IOP Conference Series: Materials Science and Engineering, 245(7), 2017

4. M. Bugler, A. Borrmann, G.Ogunmakin, P.A.Vela, J. Teizer "Fusion of Photogrammetry and Video Analysis for Productivity Assessment of Earthwork Processes", Computer-Aided Civil and Infrastructure Engineering, 32(2), $107-123,2017$

5. NG. Cheuk Fan, Effects of building construction noise on residents: a quasi-experiment Journal of Environmental Psychology $20375-385,2000$

6. D. Connolly, G. Kouroussis, O. Laghrouche , C. Ho, M. Forde” Benchmarking railway vibrations - Track, vehicle, ground and building effects", Construction and Building Materials 92, 64-81, 2015

7. A. Czemplik "Inspection of construction works according to Polish construction law", IOP Conference Series: Materials Science and Engineering, 96(1), 2015

8. P. Du, Z. Wang, E. Gamburg" Tall Buildingd as Extensions of Urban Infrastructure and Vitality" CTBUH Journal, 4, 46-51, 2015

9. M.D. Fernandez, S. Quintana, N. Chavarria, J.A. Ballesteros, Noise exposure of workers of construction sector Applied Acoustics 70 753-760, 2009

10. K.L. Fleming, Y.M.A Hashash, S. McLandrich, N. O’Riordan, M. Riemer "Novel Technologies for Deep-Excavation Digital Construction Records", Practice Periodical on Structural Design and Construction, 21(4), 2016

11. H. Gawron, „Rozwój aglomeracji miejskich i ich znaczenie dla rozwoju lokalnego rynku nieruchomości”, Journal of Managment and Finance 12, 135-151, 2014

12. R.L. Geren „Applying the Building Code: Step-by-Step Guidance for Design and Building Professionals” 2016

13. K.I. Gidado. „Project complexity: The focal point of construction production planning” Construction Management and Economics, 14(3), 213-225, 1996

14. B. Grzyl, E. Miszewska-Urbańska, M. Apollo "Building Information Modelling as an Opportunity and Risk for Stakeholders Involved in Construction Investment Process", Procedia Engineering, 196, 1026-1033, 2017

15. B.Hoła "Identification and evaluation of processes in a construction enterprise", Archives of Civil and Mechanical Engineering, 15(2), 419-426, 2015

16. J. Hong, W. Liu “Analysis of effects induced by subway train on surrounding building vibration" Journal of Vibration and Shock, 2006

17. N. Ibadov, J.Rosłon, "Technology Selection For Construction Project, With The Use Of Fuzzy Preference Relation", Archives of Civil Engineering, 61, 105-118, 2015

18. A.M. Jarkas „Contractors' Perspective of Construction Project Complexity: Definitions, Principles, and Relevant Contributors" Journal of Professional Issues in Engineering Education and Practice, 143, 2017

19. J. Jasiczak "Technologie budowlane II", Alma Mater, 2003

20. P. Jaśkowski "Methodology for enhancing reliability of predictive project schedules in construction" Eksploatacja i Niezawodnosc, 17(3), 470-479, 2015

21. P. Jaśkowski, A. Sobotka, A. Czarnigowska "Decision Model for Selecting Supply Sources of Road Construction Aggregates" INZINERINE EKONOMIKA-ENGINEERING ECONOMICS, 25(1), 13-20, 2014

22. K.M. Jaworski, A. Borowik „Planning Construction Works with Application of Disjunctive Graphs” Archives of Civil Engineering, 32, 649-661, 1986

23. K. Kähkönen "Multi-character model of the construction project definition process", Automation in construction, 8, 625-632, 1999

24. T. Kasprowicz „Proces analizy koncepcyjnej, projektowania, organizacji i realizacji przedsięwzięć budowlanych” Technical Transactions 2, 177-189, 2010

25. J. Korytarova, T.Hanak, R. Kozik, E. Radziszewska-Zielina "Exploring the contractors' qualification process in public works contracts" Creative Construction Conference, Procedia Engineering, 123, 276-283, 2015

26. M. Kozlovska, M. Spisakova, D.Mackova "Identifying the construction waste types relating to modern methods of construction”, Book Series: International Multidisciplinary Scientific GeoConference SGEM, 129-136, 2016 
27. E. Kozniewski, M. Orlowski, Z. Orlowski „Designing a supply chain of ready-mix concrete using Voronoi diagrams", IOP Conference Series: Materials Science and Engineering, 251(1), Latvia 2017,

28. B. Kożuch, T. Tatara "Impact of the vibrations on the environment caused by passages of trains at variable speed" E3S Web of Conferences 10, 1-6, 2016

29. J. Krentowski, T. Chyzy, P. Dunaj „Sudden collapse of a 19th-century masonry structure during its renovation proces" Engineering Failure Analysis, 82, 540-553, 2017

30. M. Krzemiński, "Construction Scheduling and Stability of the Resulting Schedules", Archives of Civil Engineering, $62,89-100,2016$

31. MV. Ksiażek, P. Nowak, S. Kivrak, JH. Roslon, L. Ustinovichius, „Computer-aided decision-making in construction project development" Journal of Civil Engineering and Management, 21(2), 248-259, 2015

32. X. Li, G.O. Shen, P. Wu, H. Fan, Y.Teng "RBL-PHP: Simulation of Lean Construction and Information Technologies for Prefabrication Housing Production", Journal of Management in Engineering, 34(2), 2018

33. S.L. Lusk, M.J. Kerr, S.A. Kauffman "Use of Hearing Protection and Perceptions of Noise Exposure and Hearing Loss Among Construction Workers American Industrial Hygiene Association Journal, 59, 466-470, 2010

34. T. Mandicak, P. Mesaros, J. Selin „Document management systems for data sharing in construction project management „, Technical Transactions : Civil Engineering, 113, 57-62, 2016

35. C. Martani, L. Cattarinussi, B.T. Adey, "A new process for the evaluation of the net-benefit of flexible ground-floor ceiling in the face of use transition uncertainty. The application case of an office building in London" Journal of Building Engineering, 15, 156-170, 2018

36. P. Mesaros, T. Mandicak „Exploitation and Benefits of BIM in Construction Project Management”, IOP Conference Series: Materials Science and Engineering : WMCAUS 2017. - Bristol : IOP Publishing, 245 (2017), 1-7, 2017

37. P. Mesaros, T. Mandicak "Information systems for material flow management in construction processes", IOP Conference Series: Materials Science and Engineering, 71(1), 2015

38. A.K. Nicał, W. Wodyński „Enhancing Facility Management through BIM 6D”, Procedia Engineering, 164, 299-306, 2016

39. P. Nowak, M. Skłodkowski, "Multicriteria Analysis of Selected Building Thermal Insulation Solutions", Archives of Civil Engineering, 62 (3), 137-148, 2016

40. M. Pająk Ściana szczelinowa jako obudowa głębokiego wykopu na przykładzie realizacji dla budynku Edison w Krakowie Górnictwo i geoinżynieria, 3, 319-327, 2017

41. R.I.P. Perez, A.Carballal, J.R. Rabunal, O.A. Mures, M. D. Garcia-Vidaurrazaga, "Predicting vertical urban growth using genetic evolutionary algorithms in Tokyo's Minato ward" Journal of Urban Planning and Development 144(1) 2018

42. L.S. Pheng, C.J Chuan „Just-in-time management of precast concrete components Journal of Construction Engineering and Management, 127(6), 494-501, 2001

43. E. Radziszewska-Zielina „Assessment methods of partnering relations of Polish, Slovak and Ukrainian construction enterprises with the fuzzy logic", Archives of Civil Engineering, 57(1), 87-118, 2011

44. E. Radziszewska-Zielina, B. Szewczyk „, Supporting Partnering Relation Management in the Implementation of Construction Projects Using AHP and Fuzzy AHP Methods" WMCAUS 2016Book Series: Procedia Engineering, $161,1096-1100,2016$

45. E. Radziszewska-Zielina, B. Szewczyk „Examples of actions that improve partnering cooperation among the participants of construction projects", IOP Conference Series: Materials Science and Engineering 251(1), 012051, 2017

46. E. Radziszewska-Zielina, B. Szewczyk „Sensitivity analysis of the controlling partnering relations model to changes in membership functions of the variables", Scientific Review Engineering and Environmental Sciences, 26(2), 219225,2017

47. E. Radziszewska-Zielina, E. Kania „Problems in Carrying Out Construction Projects in Large Urban Agglomerations on the Example of the Construction of the Axis and High5ive Office Buildings in Krakow" MATEC Web of Conferences 117, 2017

48. E. Radziszewska-Zielina, G. Śladowski „Proposal of the Use of a Fuzzy Stochastic Network for the Preliminary Evaluation of the Feasibility of the Process of the Adaptation of a Historical Building to a Particular Form of Use" IOP Conference Series: Materials Science and Engineering, 245(7), 2017

49. E. Radziszewska-Zielina, G. Śladowski „Supporting the selection of a variant of the adaptation of a historical building with the use of fuzzy modeling and structural analysis" Journal of Cultural Heritage, 26, 53-63, 2017

50. E. Radziszewska-Zielina, G. Śladowski, M. Sibelak „Planning the reconstruction of a historical building by using a fuzzy stochastic network", Automation in Construction, 84, 242-257, 2017

51. E. Radziszewska-Zielina, M. Glen, , The application of the Electre I method for the selection of the floor solution variant, Advences and Trends in Engineering Sciences and Technologies, 359-365, 2016

52. E. Radziszewska-Zielina, R.Rumin, "Analysis of investment profitability in renewable energy sources as exemplified by a semi-detached house”, E3S Web Of Conferences, 10, 00079, 2016 
53. E. Radziszewska-Zielina" The Application of Multi-Criteria Analysis in the Evaluation of Partering Relations and the Selection of a Construction Company for the Purposes of Cooperation" Archives of Civil Engineering, 62(2), 167-182, 2016

54. J. Rosłon, M. Seroka, „Multicriteria Selection of Water Insulation Technology for Foundation Walls in an Existing Building", Archives of Civil Engineering, 62(3), 167-176, 2016

55. L. Runkiewicz, J.Sieczkowski „Problemy techniczne budowy obiektów na terenie istniejącej gęstej zabudowy” Przegląd Budowlany 9, 18-23, 2015

56. A. Sobotka, A. Czarnigowska "Analysis of supply system models for planning construction project logistics" Journal of Civil Engineering and Management 11, 73-82, 2005

57. A. Sobotka, P. Jaśkowski, A. Czarnigowska "Optimization of aggregate supplies for road projects" TRANSPORT RESEARCH ARENA 2012 Book Series: Procedia Social and Behavioral Sciences, 48, 838-846, 2012

58. A. Sobotka, E. Radziszewska-Zielina, E. Plebankiewicz, K. Zima, M. Kowalik „Realizacja robót ziemnych w opinii wykonawców budowlanych" Przegląd Naukowy - Inżynieria i Kształtowanie Środowiska, 63(1), 3-13, 2014

59. A. Sobotka, M. Blajer "Earthworks Logistics in the high density urban development conditions-case study" IOP Conference Series: Materials Science and Engineering, 251(1), Latvia 2017,

60. X. Song, J.Xu, C. Shen, F.Pena-Mora, „Conflict resolution-motivated strategy towards integrated construction site layout and material logistics planning: A bi-stakeholder perspective" Automation in Construction, 87, 138-157, 2018

61. K. Stypuła, T. Tatara „Wybrane wyniki badań wpływu drgań tramwajowych na budynki w Krakowie” Transport Miejski i Regionalny, 7, 2015

62. V. Sundquist, L.Gadde, K. Hulthen, „Reorganizing construction logistics for improved performance” Construction Management and Economics, 1-17, 2017

63. M. Van Den Berg, H.Voordijk, A.Adriaanse, T. Hartmann “Experiencing Supply Chain Optimizations: A Serious Gaming Approach”, Journal of Construction Engineering and Management, 143(11), 2017

64. E. Vareni, G. Pozoukidou, A. Sdoukopoulos „The effect of urban density, green spaces and mobility patterns in cities' environmental quality: An empirical study of the metropolitan area of Thessaloniki”, Spatium, 1, 8-17, 2015

65. H. Wood, P.Ashton "Factors of complexity in construction projects" Association of Researchers in Construction Management, ARCOM 2009, 857-866, UK, 2009

66. J. Xiao, X. Li, Z.Zhang, J. Zhang, "Ontology-Based Knowledge Model to Support Construction Noise Control in China", Journal of Construction Engineering and Management, 144(2), 2018,

67. W. Yi, H.L.Chi, S. Wang "Mathematical programming models for construction site layout problems", Automation in Construction, 85, 241-248, 2018

68. J. Zimmermann „Real estate as an object of engineering in practice, science and teaching”, Bauingenieur, 90(March), $115-128,2015$ 


\section{LIST OF FIGURES AND TABLES:}

Fig. 1. Requirements for experts according to the filtering questionnaire. Original work

Rys. 1. Wymagania względem eksperta zgodnie z kwestionariuszem filtracyjnym. Opracowanie własne

Fig. 2. Graph showing examples of constraints and problems that appear during the carrying out of construction projects in the centres of urban agglomerations. Original work based on interviews with experts.

Fig. 2. Schemat przykładowych ograniczeń i problemów pojawiających się przy realizacji przedsięwzięć budowlanych realizowanych $\mathrm{w}$ centrum aglomeracji miejskich. Opracowanie własne na podstawie przeprowadzonych wywiadów z ekspertami

Fig. 3. Results of the survey study, showing whether experts agree that the difficulties that occur in the centres of urban agglomerations can have an effect on the selection of construction technology for a construction project. Original work

Fig. 3. Wynik sondażu pokazujący, czy w opinii ekspertów utrudnienia występujące w centrum aglomeracji miejskich mogą mieć wpływ na dobór technologii realizacji przedsięwzięcia budowlanego. Opracowanie własne

Fig. 4. Results of the survey study, showing whether experts agree that an appropriately selected technology can completely or partially alleviate the difficulties resulting from carrying out a construction project in the centre of an urban agglomeration. Original work

Fig. 4. Wynik sondażu pokazujący, czy w opinii ekspertów odpowiednio dobrana technologia może całkowicie lub $\mathrm{w}$ pewnym stopniu zniwelować utrudnienia wynikające $\mathrm{z}$ realizacji przedsięwzięcia budowlanego $\mathrm{w}$ centrum aglomeracji miejskich. Opracowanie własne

Fig. 5. Results of the survey study showing whether the experts agreed that there is cooperation between the Designer and General Contractor. Original work

Rys. 5. Wynik sondażu pokazujący, czy w opinii ekspertów istnieje współpraca pomiędzy projektantem i Generalnym Wykonawcą. Opracowanie własne

Fig. 6. Results of the survey showing who, in practice, makes the final decision regarding technology selection. Original work

Rys. 6. Wynik sondażu pokazujący, kto w praktyce podejmuje ostateczną decyzję odnośnie doboru technologii. Opracowanie własne 


\section{PROBLEMY DOBORU TECHNOLOGII REALIZACJI OBIEKTÓW BUDOWLANYCH W CENTRUM AGLOMERCJI MIEJSKICH}

Słowa kluczowe: technologia, organizacja, przedsięwzięcia budowlane, aglomeracja miejska

\section{STRESZCZENIE:}

Realizacja przedsięwzięcia budowlanego to w znacznym stopniu skomplikowany proces zależny od niepowtarzalnych czynników zewnętrznych oraz cech indywidualnych danej inwestycji. Realizacja przedsięwzięcia budowlanego, zlokalizowana w centrum aglomeracji miejskiej wiąże się z dodatkowymi problemami i utrudnieniami technologicznoorganizacyjnymi. Wielu autorów opracowań naukowych wskazuje także na różnorodne problemy pojawiające się w trakcie realizacji obiektu budowlanego w centrum aglomeracji miejskich oraz problemy z doborem technologii.

Przeprowadzono badania sondażowe w grupie ekspertów z branży budownictwa (osoby spełniające kryterium pracy w budownictwie powyżej 10 lat, realizujące kontrakty o wartości powyżej $50 \mathrm{mln}$ oraz mające doświadczenie w realizacji przedsięwzięć w centrum aglomeracji miejskich). Każdy z ekspertów wymienił szereg pojawiających się problemów i utrudnień związanych z realizacją obiektów budowlanych w centrum miasta. Podkreślanym problemem jest szeroko pojęta logistyka, zarówno placu budowy jak i całego miasta. Duży zakres inwestycji budowlanych przy jednoczesnych ograniczeniach placu budowy powoduje problemy organizacji miejsca budowy. Jednocześnie występuje problem z dostawami, ze względu na opóźnienia spowodowane korkami ulicznymi i innymi czynnikami. Koniecznością jest zaplanowanie i zrealizowanie licznych uzgodnień w urzędach miejskich ze względu na potrzebę zajmowania pasów drogowych oraz wprowadzenie tymczasowej organizacji ruchu. Należy brać pod uwagę oddziaływania dynamiczne, wpływające zarówno na realizowany obiekt, jak i na otaczające go środowisko. Jak podkreśla większość ekspertów, odpowiednio dobrana technologia realizacji obiektu budowlanego może w dużym stopniu wpłynąć na sukces realizowanej inwestycji. Utrudnienia pojawiające w się w dużych aglomeracjach miejskich mogą mieć wpływ na dobór technologii, a odpowiednio dobrana technologia może całkowicie lub w pewnym stopniu zniwelować wpływ tych utrudnień na realizację przedsięwzięcia budowlanego. Przeprowadzone badania pokazują również, w jaki sposób podejmowana jest decyzja wyboru technologii realizacji obiektów. Jak wynika z badań, brakuje narzędzi wspomagających podejmowanie decyzji w tej kwestii, a w większości przypadków decyzja ta jest podejmowana na podstawie rozmów pomiędzy uczestnikami przedsięwzięcia oraz na podstawie ich doświadczenia własnego. Niniejsze badania stanowią więc uzasadnienie i wstęp do podjęcia tematu opracowania narzędzia wspomagającego (systemu informatycznego), które będzie przydatne przy podjęciu decyzji odnośnie wyboru technologii realizacji obiektu budowlanego w centrum aglomeracji miejskich. 